\title{
THE HEBREW SOURCES OF TORTOSA'S DISPUTATION
}

\author{
FRANCESCO BIANCHI
}

Associazione Biblica Italiana

\begin{abstract}
The Disputation or Cathechesis of Tortosa with its sixty-nine sessions (February 7 , 1413-November 12, 1413) was the longest of the Jewish Christian encounters in the Middle Age. Stirred by the Avignonesian Pope Benedict XIII, Geronimo de Sancta Fide, olim Yehoshua ha-Lorki, summoned a group of Catalan and Aragonese rabbis to inform them that the Messiah was already came. Not only the Papal notaries recorded the excruciating debates, but also two Hebrew sources: the anonymous and fragmentary letter published by Halberstam in 1868 and the chapter 40 of the Shebet Yehuda. They encompass the first nine sessions carried out orally, before the Pope requested for written texts to be debated lately. Since these sources disagree on many details, this paper aims at examining them anew. That examination has shown that the anonymous account is more accurate than the fictional report of the Shebet Yehuda as far as the internal chronology of the sessions, the speeches of the Jewish delegates and their identities are concerned. The internal evidence leads us to subscribe with Riera i Sans in ascribing its authorship to Bonastruc Desmestre from Girona, who was at Tortosa on request of the Pope. He probably knew other Jewish chronicle and added some new materials from the Vikkuach Ramban, Salomon Ibn Verga, the author of Shebet Yehuda, built upon this chronicle and created a fictional account around Vidal Benveniste or the 'ideal' portrait of the Pope and added some materials from the Latin Protocols or from unknown Jewish sources.
\end{abstract}

KEYWORDS: Disputation of Tortosa, Messiah, Jewish Christian Polemics, Benedict XIII, Shebet Yehuda

No study dealing with the Jewish-Christian debates in the Middle Age could be complete without taking into account the disputation of Tortosa ${ }^{1}$ (Schreckenberg 1994: 434-481, Krauss-Horbury 1996: 169-176). If compared to the earlier disputations, this event at once amazes for its length. Although with some intervals, the disputation lasted from February 7, 1413 to November 12, 1414 for sixty-nine sessions. The first 45 sessions in Tortosa dealt with the Messiah, whereas the other 24 in San Mateo and Peñiscola were about the errors of the Talmud. That partition roughly matches

* $\quad$ FRANCESCO BIANCHI (PhD 1993, University of Turin) teaches Catholic religion at an intermediate secondary school. He is also a member of the Associazione Biblica Italiana.

1 I still use the term Disputation, although being aware that The Disputation of Tortosa was rather a Cathechesis where the truth of the Christian Faith was not at stake. 
the two tractates penned by Geronimo de Sancta Fide, who stood on the Christian side. With the name of Yehošua' haLorki, he was a learned member of the Jewish aljiama of Alcañiz (Williams 1935: 261-266, Sáenz Badillos-Targarona Borrás 1988: 125-126) and a fierce advocate of Judaism against Pablo de Sancta Maria, olim Šělomoh ha-Levi (Sirat 1990: 447-451), until the conversion precipitated by Vicente Ferrer's predication (Vendrell 1953: 87-104). As physician of the Avignonesian Pope Benedict XIII (Girgensohn 1989, Vaquero Piñeiro 2000), the successor of Clement VII and the competitor to the popes of the Italian obedience, Geronimo de Sancta Fide wrote Ad convincendum perfidiam judaeorum - a collection of haggadic passages germane to Jesus (1412)—and De Judaeis erroribus ex Talmuth (1413). The two works will be eventually published under the title Hebraeomastix (Orfali 1987). His goal was to arrange a small disputation ${ }^{2}$ in his hometown with r. Astruc ha-Levi, but Benedict's personal interest ${ }^{3}$ led to summon at Tortosa a group of rabbis and scholars to receive information about Christian faith and to answer the Christian 'champion'. The most noteworthy feature of the disputation of Tortosa lies in its multifarious sources (Posnanski 1922: 17-46). A Latin protocol written by the Papal notaries registered the sixty-nine sessions. Pacios López (1957: 31-34) edited it based on three codices respectively housed in Escorial, in the Vatican Libraries and in Gerona. Two Hebrew documents illustrate the nine sessions carried out orally, before the debate was arranged for written texts to be studied and then debated. The first source is an anonymous, but incomplete report of these nine sessions. It was kept in the manuscript $\mathrm{nr} .221$ kept at the Austrian National Library ${ }^{4}$ (Schwarz 1931: 156-159), but lost after the Second World War. Halberstam (1868: 44-55) was the first to edit it and to point out its historical value. Nevertheless, this firsthand report has always been belittled in behalf of another Hebrew source namely the chap. 40 of Šebet Yěhudah (Shohet-Baer 1947: 74-87, henceforth SY). Conceived as a vivid account of the persecutions the Jews suffered in the Christian world, the genesis of this book is still uncertain (Baer 1923, Cantera y Burgos 1924, Caro 1991: 9-17, Cohen 2017). It is unclear if the Spanish converso R. Yěhudah ibn Verga (15th century) conceived the work, but the nephlic and private dispute between Jews and Christians in Spain during the Late Middle Age.

3 Not only Benedict XIII had a library rich with codices relating to the Judaism, but when he still was the cardinal Pedro de Luna, he debated at the Cathedral of Pamplona in 1379 with Šem Tob ibn Šapruṭ (Niclós 2002: 14-15).

4 The manuscript by an Italian hand about the XVI century numbered a series of polemical texts as the Vikkuah Ramban and Nahmanides's commentary to Isaiah 52: 1353. 
ew Šělomoh ibn Verga completed it between 1506 and 1520. His Yosef published a first version of the book in Adrianopolis around 1554, whereas a revised and augmented edition saw the light ten years later. In Šělomoh ibn Verga's work the disputation of Tortosa, though erroneously locating it in Rome, had a pivotal role. Built upon the allegedly Abunastruc's letter to the community of Gerona, the account focused rather on the pump, the circumstances and the characters of the event than on the historical truth. The relationship between these Hebrew sources has been explained in different and often puzzling ways (Riera i Sans 1974, Cohen 2011). For instance, I. Loeb (1892) held that both J and SY autonomously abridged and reworked a source alone penned by the Jewish delegates. Nevertheless, Loeb stressed the many doubtful and legendary elements present in SY. In his seminal studies on the Disputation of Tortosa, F. Baer (1923, 1962) agreed on the fact that both the letters were sent to the Jewish communities, but he pointed out the peculiarities of all the sources. The Hebrew sources and the Latin Protocols as well pursued their own agenda and freely reworked these sources above all as far as the speakers or the numbers are concerned. Baer also remarked J's interest in the course of the dispute, whereas Bonastruc's letter highlighted the achievements and the speeches of the Jewish delegates. SY would have used that letter, now lost, although spicing the text with a series of additions for rendering it more interesting. Riera i Sans (1974: 57-68) has been the only scholar to revaluate J's account. The names of the months, of the individuals and of the offices led Riera $\mathrm{i}$ Sans to emphasize the Catalan background of J's author and to identify him with Bonastruc Desmestre (Riera i Sans 1974: 19), a delegate from Gerona's aljiama, whose presence was expressly requested by the Pope (Simonsohn 1994: 574-575, nr. 521). Šělomoh ibn Verga would have used his report, after having changed the Catalan names into the Castellan ones and having made several additions. Lastly, J. Cohen (2016: 38-39) has argued for almost three sources in the account of the Šebet Yěhudah: the shorter J report, some information drawn from the Latin Protocols and another unknown Jewish source. His author would have interwoven them with many entertaining additions.

In my opinion, time is ripe for a fresh examination of the troublesome relationship between the Hebrew sources. I will examine first the nine sessions day by day according to the accounts of J and SY and I will underline the peculiarities of these texts as far as the chronology, the topics, the speakers and if needed the comparison with the Latin protocols ${ }^{5}$. The results of that analysis will let to evaluate whether the relationship between to publish in next future. 
the Hebrew sources held by scholars is still compelling or if Riera i Sans's hypothesis might be revaluated and which would be the effects for the historical reconstruction of Tortosa's disputant.

J: February 7, 1413, Day 1, Latin Protocols

J's account agrees with the Latin Protocols (Pacios López 1957b: 19) and with M. de Alpartil's contemporary chronicle (Ehrle 1906: 222) on the fact that the encounter began on February 7, 1413. The first lines provide both the date according to Christian era for marking out that the event was alien to the Jewish History and the place of the meeting namely the Bishop's Palace at Tortosa. The attendance of cardinals, prelates, theologians, chevaliers and noblemen (one thousand people in all) and of the Jewish members of Tortosa's aljiama is noticed as well. J also referred to the twenty-two Jewish representatives from Catalonia and Aragona who came to Tortosa upon a written request by the Pope for answering to $\mathrm{m}$. Geronimo de Alcañiz's booklet about the Messiah. J just remembers t his Jewish name Yehošua' haLorki. Diving into the document, only six among the Jewish representatives will take part in the discussion ${ }^{6}$. They were $r$. Todros al Costantini; $r$. Zěrahyah ha-Levi; r. Mattityahu ha-Yișhari; r. Yosef Albo; r. Astruc ha-Levi; r. Šĕlomoh Maimon. The same rabbis, with the addition of Bonastruc Desmestre and Mošeh Abenabez, were also recorded in M. de Alpartils (Ehrle 1906: 202).

Benedict XIII emphasized that the disputation did not aim at putting in discussion the Christian faith and its basic truths, but at proving through the Talmud that the Messiah was already come. Without elaborating more, $\mathrm{J}$ only added that the Pope joked about this. Just at the end of the first day, $\mathrm{J}$ summed up Geronimo's arenga-this name describing the opening of a document or of a speech as well-which is built upon Isaiah 1:18-20. Geronimo alluded to the 'philosophical' and theological proofs he would have put forth about the fourfold movement ${ }^{7}$ and to the fact that the disputation was not compulsory. J skipped the description of the meanings of the Scripture held by the Hebrew interpreters ascribed to Geronimo by the Latin Protocols (Pacios López 1957b: 20-21). On the contrary, after having hinted at Rashi's commentary on Eljiah and the prophets of Baal, J sketched Todros ben Yahia's answer to Geronimo's arenga. He asked God to arouse 
Pope's mercy through Psalm 85:8: 'Show us, o Lord, your mercy and give us your shelter'. Both of them are missing in the Latin Protocols.

SY: No date, The Prologue

Šělomoh ibn Verga began quoting a letter of the great sage Abu Astruc ${ }^{8}$ to the community of Gerona about this great danger. In comparison to J, the date follows the Jewish year 5116 and is off the mark. It matches to the Christian year 1356 namely to say fifty-six years before the disputation. The choice of Jewish chronology probably makes the disputation falling on the Jewish history of persecution and harassment. As to the mistaken year, I wonder whether it could hide a pointe against the messianic hopes raised in that occasion by Nachmanides's speculation. In fact, Naḥmanides's Sefer Geu'lah pointed out that the year of the redemption would have begun in 1358 (according the Christian calendar) that's to say in the Jewish year 5118 (Caputo 2007: 140-141). The dramatic overture introduces Yehošua' haLorki with his Christian name and his malevolent attempt to prove, through the Talmud, that the Messiah had come and that he was Jesus. Moreover, by means of the first letters of his Christian name, Šělomoh ibn Verga forged the epithet megadef namely 'the slanderer'. The strong devaluation of Yehošua' ha-Lorki fits well with the general description of the 'apostate'. He would have to crush 'the true religion' for becoming a true Christian and for slaying the people with lies (Cohen 2011: 423-424, Cohen 2016: 43-44). The prologue ends with a set of biblical quotations, which emphasize the impending danger, and the saving presence of the Lord.

SY: January 1st, Day 1

On the contrary, SY set the beginning of the disputation on January 1. Although the Pope summoned the rabbis to reach Tortosa within the first two weeks of January, the disputation indubitably began on February 7. I wonder whether the date in SY hides a 'polemical' reference to the feast of the Circumcision of Jesus, which was celebrated just on January 1. This could be possible, since Š ̌̌lomoh Ibn Verga was forcibly baptized and lived until 1506 in a Christian world.

Having already introduced Geronimo de Sancta Fide, Šělomoh ibn Verga offered an inventory of sixteen Jewish rabbis and notables being in Tortosa along with their hometowns ${ }^{9}$. They are: Zerahyah ha-Levi; d. Vidal

8 Cano 1991: 168, n. 2 identified Abunastruc with the same Astruc ha-Levi. He would have been the author of that letter along with r. Zerahyah ha-Levi Ferrer.

$9 \quad$ On the historical and economical situation of these aljamas, see Assis 1997. 
Benveniste and r. Mattityahu ha-Yișhari from Zaragoza; d. Šemu'el Levi and r. Mošeh ben Musa from Catalayud; d. Todros AlCostantin from Huesca; d. Yosef ben Ardut and d. Meir Haligoah from Alcañiz; don Astruc from Daroca; r. Yosef Albo from Monreal, d. Yosef ha-Levi from Monzon and rabbi Yom Țob Qarcosa; from Montalban Abu Janada; from Belchite don Yosef Albaleg; the wise Bongoa ${ }^{10}$ and the rabbi Todros ben Yahia from Gerona. A last name seemingly fell, as the phrase 'this one was dreadful' does not have a subject. Šělomoh ibn Verga would have found such a catalog on the edge of its source and he would have transcribed it into his own work. May be the case, the catalog raises several problems. Some members are unknown, although Ben-Shalom (2013: 101-103) has been able to detect behind Abu Janada of Montalban the scribe Yom Ṭob ben Hannah, author of poems and letters. The two editions of SY also differ about names and hometowns. The first edition rightly makes r. Yosef Albo coming from Daroca, but the second refers to Monreal as his hometown. Another case at point is the unknown 'Mordechai from Huesca' opposite to 'Todros Al Costantini'. Even more bewildering is the historical identity of Don Vidal who appears problematic already in the two editions of SY (Riera i Sans 1974: 29-30, note 6). The first only has this name, whereas the second also adds the patronymic 'ben Benveniste'. Through the years, scholars have put forth at least three proposals to solve that mystery. The first proposal identifies him with Don Vidal, the son of Bonafos de la Cavalleria and the learned pupil of Šělomoh Bonafed. Not only would he have attended the disputation as spokesperson of the Jewish delegation, but also after its ending, he would have answered to Geronimo de Sancta Fide writing the polemical tractate Qoděs Qodašim (Krauss-Hornbury 1996: 176, 244). Since Vidal Benveniste de la Caballeria was christened Gonzalo on February 2, 1414 together with the father and a part of the family (Sáenz Badillos-Targarona Borrás 1988: 117), this proposal seems unconvincing at least for its second part. Why would Šělomoh ibn Verga have extolled a man who was later apostatized? An alternative solution would favor a junior and less illustrious member of de la Caballeria's family namely Don Vidal Benveniste ibn Labi. He would have not apostatized and would have penned the polemical tract Qodeš Qodašim against Geronimo de Sancta Fide? (Saenz Badillos-Targarona Borras 1988: 117). In this case, the problem seems the contrary. Why would have the author of SY ascribed to him such a great role in the disputation of Tortosa? The last proposal credits to Šělomoh ibn Verga the will of celebrating a descendant of Vidal Ben Benveniste who negotiated with the Portuguese King the settlement of a group of Jews from Spain in the fateful Š̌̌lomoh Bonafed? (Sáenz Badillos-Targarona Borrás 1988: 38). 
1492 (Baer 1923: 46ss, Cantera y Burgos 1924: 104). As Šělomoh ibn Verga did the same with other characters of his work, this last solution could be preferable.

The Jewish delegates gathered before meeting the Pope and entrusted the arenga to the wise Don Vidal. They also agreed to behave respectfully between them-contrary to the habits of the Jewish scholars-and before the people, the cardinals and the Pope. Describing this gentlemen's agreement, Šělomoh ibn Verga hinted at the danger of division and of internecine polemics well known in Jewish History. Up to now, no information was given about the place of the disputation. The later reference to 'the greats of Rome' betrays that Š̌lomoh ibn Verga was just thinking of Rome, the seat of the Pope. Some scholars think that his source did not refer to the place yet, but as we have seen above, J's reference to Tortosa is clear. The seventy seats for the prelates (cardinals and bishops) in golden vests perhaps refer to the seventy nations on the earth whose the Talmudic tractate Sukkah 55B speak of 'The one thousand men' quoted in J became Rome's nobles, who assiduously attended the sessions. The character of the Pope also underwent a more singular change. Šělomoh ibn Verga transformed him in a temperate Renaissance's Lord (Cohen 2011: 424-425, 2017: 43-44) who kindly spoke to the Jews, inquiring about their birthplace and acknowledging Israel's election. He presented the disputation as an open and fair discussion. Geronimo wanted to proof that the Messiah already came and the argument would have confirmed whether he was right or not. The Pope also worried for the well-being of his hosts, providing them a dwelling and kosher food too! That care for the Jewish delegates is contradicted by a statement of r. Astruc who during the fifty-third session celebrated on February 151414 ascribed the ignorance of the Jewish not only to their worries for their families and their communities, but also to their bad conditions of living and the severe lack of food (Pacios López 1957b: 440-441; Maccoby 1993: 84). We do not know whether these latter difficulties arose just in San Mateo where from the 45th session the disputation moved on or they were already present in Tortosa. A last pointe about the Jewish fears (Cohen 2017: 48-49) closes the first day.

\section{SY: Day 2}

By creating the prologue, Šelomoh ibn Verga moved a part of the first session to the second day. Against the background of a magnificent stage and of the growing fear of Jewish delegates, Šělomoh ibn Verga presented Geronimo's arenga with its reference to Isaiah 1:18-20. Now the stage was set for Vidal Benveniste's speech. This latter performed the arenga in Latin, getting the Papal praise! Moreover, Šělomoh ibn Verga created a shortly 
poignant protest of the Jewish delegates against Geronimo's use of Isaiah 1:18-20. Actually, Geronimo referred to a spiritual sword and to the hell's sufferings, as the Church does not have a secular sword (Pacios López 1957b: 27). The Pope's mocking answer about Geronimo's jewishness also is remarkable. Don Vidal's speech is just sketched, whereas Šěmu'el ha-Levi, sometimes identified with the poet Shemu'el Bonastruc ha-Levi (Sáenz Badillos-Targarona Borrás 1988: 106-107), replaced Todros ben Yahya as the first Jewish respondent.

The closing of the 'second day' is quite noteworthy. As the Jewish delegates rose against the use of philosophical arguments, the Pope would have let them to argue only with their tradition. The Latin Protocols confirms it (Pacios López 1957b), although many of Jewish delegates were well acquainted with the Scholastic philosophy (Ben Shalom 2003). The session ended with the description of noblemen and princes, who ushered the Jewish delegates back home. Is there the reminiscence of the popular turmoil surrounding the Jews and of the need of protecting them? The last act took place in the local synagogue. Zěrahyah's derasha (Sáenz Badillos-Targarona Borrás 1988:202) started from the following remark: 'Like is cured by like and opposite by opposite'. Scholars deemed it an indirect quotation from Aristotle's De Natura, but H. Maccoby (1993: 220-221) referred rather to a 'discussion of homeopathy and allopathy'. The rabbi would have applied a medical example, whose many of his listeners were conversant with, to the Spanish Jewry entangled between the conversions to Christianity and the Averroism (Foa 1999: 99-104). The Christian propaganda would have homeopathically brought those Jews on the edge of the conversion back to the Judaism. Otherwise, the same Christian propaganda would have allopathically persuaded the Jews fascinated with Averroism to reconsider the rationality of the Jewish faith. Although enthralling, that explanation seems too farfetched, as the references to the homeopathy are later ${ }^{11}$. A free quotation from Aristotle is still preferable.

\section{J: February 8th, Day 2, Latin Protocols}

A vivid description of the Christian and Jewish public waiting for the delegates opens J's second day. Geronimo declared that the event was not a disputation at all, but a demonstration by means of the Talmud that the Messiah was already came. He quoted two excerpts from Aboda Zara 9a and Sanhedrin 97a-b: 'Six thousand years lasted the world: two thousand years of chaos, two thousand years of Law and two thousand years and the Messi- 
ah will die. For our faults, they were the things which happened and he did not come'. These quotations were well known to Julian of Toledo's De Consummatione mundi, to Agobard of Lion (Roth 1986, Del Valle 1997: 121-130) and Ramon's Marti’s Pugio Fidei as well. Zěrahyah ha-Levi-whom the Latin Protocols calls Rabbi Ferrer Saladin-endeavored to illustrate the conditions for the coming of the Messiah, but the Pope asked for an explanation of that haggada. Under pressure, Zěrahyah claimed that Israel's sins prevented the Messiah's arrival. Geronimo's reply ascribed a part of the haggada to the academy of the prophet Elijah and visited the sins upon the prophet's generation. Now, J displays a long paragraph, whose authorship is under scrutiny. Zěrahyah dwelt on the first two thousand years of chaos for refuting the doctrine of the original sin. Some upright men as Methuselah and Noah would have made the chaos less absolute. Although the textual station is quite confused, we can follow the internal chronology of the six thousand years. After the first two thousand years of chaos, he listed the key dates of the following two thousand years: the calling of Abraham stood at the beginning of it; the year 2448 marked the exodus from Egypt and the gift of the Torah; the devastation of the temple fell in year 3838. Accordingly, the exile did not last for 172 years, but only for 70 years. This mistake would have undermined the calculation about the year 4000 as the year in which the Messiah came. A student of Yehošua' ben Perahiia, Jesus would have lived during the kingdom of Alexander Yannai. Accordingly, he would have born in the year 3675 from the world creation and died in 3688. Besides, of the pars destruens, Zěrahyah offered the Jewish interpretation: the Messiah would have come during the last two thousand years, as the rainfalls can occur from Rosh Hashanah to Pesach. Nevertheless, his coming at the beginning or at the end would have hung on the conversion and on the good deeds of Israel.

Riera i Sans ascribed this long paragraph, which covers all the session to Bonastruc Desmestre. He would have offered his own exegesis of the text sub specie homiliae (Riera i Sans 1974: 18, note 6). The comparison with the Latin Protocols hardly settles the question. Not only had the Papal notaries recorded quite synthetically Geronimo's and Zěraḥyah's exchanges, but they also registered the words of two other Jewish delegates, Šělomoh Yisah (or Šělomoh Maimon from Tortosa) and R. Astruc ha-Levi, both missing from J. According to the Papal notaries, the otherwise unknown Šělomoh Yisah argued that the Messiah would have come at the end of the last two thousand years (Pacios López 1957b: 32). Geronimo found support for the Talmudic truth in the biblical Noah: as the Scripture taught that he lived 950 years, he must have been so. Otherwise, r. Astruc understood the Talmudic auctoritas by means of the philosophy. The two thousand years of vanity would refer to the question whether the world was created or uncre- 
ated, whereas the four thousand years of the Law and of the Messiah whether the Messiah came or not. If we follow Riera i Sans's proposal, J drew from Nahmanides's Vikkuah the reflection about the primeval history, the original sin and the Antediluvian Patriarchs. Among these latter, there was the wise and upright Noah.

SY: Day 3

In Š̌̌lomoh ibn Verga's account of that session, Don Vidal skirmished about the conditions for the coming of the Messiah. He would have quoted 'the naturalist' namely Aristotle-about the need to debate 'first the essence of the problem and then its conditions'. Šělomoh ibn Verga was more interested of logical problems than of the exegetical ones. Accordingly, the debate dwelt on the logical validity of the Talmudic excerpts, especially when two affirmations could be true at the same time and who bears the onus of the proof. Oddly enough his account extolled the Pope's behaviour. Not only subscribed he to this forensic point of view, but he also lashed his sarcasm against Geronimo's logical faults: 'The man has lost the character of a Christian disputant and returned to being a Jewish one, running away to another side when the first has proved weak'. Geronimo also disappointed the other prelates, since he did not bring any sure proof. Other valuable additions are both Yosef Albo's intervention and the delegates' speech. By means of these dramatis persona, as in the Latin Protocols is r. Mattityahu ha-Yișhari to speak, Š̌lomoh ibn Verga voiced his view about the exile. The exile will end 'when Israel will be ready and will repent'. Accordingly, the Messiah will come at the beginning, in the middle or at the end without any relation to the two thousand years. With one voice, the delegates answered the Pope's objection about Messiah's arrival, by saying that the Redeemer will come rather for those being in exile and in bondage than for those living in peace. For the time being, in spite of their fidelity to the Torah the prosperity and the power still belong to the Christians. Nahmanides has already noted it in his debate with Paul Christiani. Nevertheless, the Jews would have been faithful to the Torah unless God ordered otherwise. When the session closed, Geronimo seemed almost defeated. The Jewish delegates shared this feeling, as they went to eat with happiness of hearth.

\section{J: February 9th, Day 3, Latin Protocols}

At the beginning of the third day, Geronimo submitted another famous Talmudic piece: 'The world would have lasted not less of 85 jubilees and in the last Jubilee the son of David will come'. Mattityahu ha-Yishari pointed out the flawed calculations behind this saying, which Julian of Toledo and 
Agobard of Lyon (Roth 1986: 45-65) also knew. Multiplying the number of the jubilees for the number fifty, the 4250 did not match with Jesus' date. Geronimo's reply, which according to Latin Protocols found the approval of the Pope, aimed at proving that the Messiah has come, without any reference to the historical Jesus.

Now J clumsily states that 'there were many quarrels between them'. It is unclear to whom this pronoun did refer. We could refer it to Mattityahu haYishari and to the Christian attendees, but we cannot rule out that an argument arose between the Jewish delegates about a quotation from Sanhedrin 97b which runs: 'Burns the soul of those who calculate the end of the time'. The Pope seemingly blamed it as outrageous to the book of Daniel. Geronimo attacked the Talmud's lies. Once again, Mattityahu haYișhari answered that Daniel did not make any calculation, since he was a prophet. As matter of fact, the absence of authorities about Daniel confused the Jewish delegates. Requested with an answer, they followed R. Yosef Albo (Rauschenbach 2002: 11-47), who delayed the waiting for the Messiah up to the last jubilee of the world. According to J, the cardinals asked for the book and read it. It is impossible to settle down whether the book was Ramon Marti's Pugio Fidei or the tractate Sanhedrin. The cardinal Andres Bertran, olim Moses of Valencia, who converted to the Judaism during the pogroms of 1391, knew the Hebrew pretty well to check the book. Although subscribing to the Jewish interpretation, they asked whether the arrival of the Messiah outside of the eight-fifth Jubilee would have prolonged the world. Geronimo replied by means of a quotation from Sanhedrin 99a which set the days of the Messiah to forty years. The Jewish delegates refuted the proof as inconclusive. Just at the end, J noticed that the papal notaries kept a record of their words.

At this stage, the comparison with the Latin Protocols becomes quite interesting. First, the papal notaries ascribed the calculations about the jubilee to $r$. Š ̌rlomoh namely to say to the same Rashi and the confutation to the magister Šělomoh Yisaḥ. Second, they recorded r. Yosef Albo's angry reaction to Geronimo's words and his pride for being a Jew: 'Magna cum furia... r. Iuse Albo sic inquit: Posito Messiam michi probari iam venisse, non putarem deterior esse judeus'. Third, they lack the debates about the book of Daniel and the following blame on those calculating the times. Fourth, they registered the Pope's objection that the coming of the Messiah after the 85 jubilee would have left too little time before the end of the world. Fifth, Geronimo remarked that the coming of the Messiah at the end of the eighty-five jubilee would not have left room for a flourishing Messianic age. The Latin Protocols gladly lingered on the troubled reaction of the 'copiosa multitude judeorum' before his 'incongruent and vacuous interpretation' (Pacios López 
1957b: 37) of their representatives. They would have recognized Geronimo's truth.

\section{SY: Day 4}

Being a day ahead in comparison to J and the Latin Protocols, SY started the fourth day with the quotation of Sanhedrin 97 followed by answer of $r$. Mattityahu ha-Yișhari. Nevertheless, the argument between the Jewish delegates and Geronimo is once again different. Geronimo used a philosophical ruse. He generally held that the Messiah came, without any further explanation on his identity and his chronology. The Jews focused on the real identity of such a Messiah-if not Jesus, was he Matthew the fool or Marvesti the stupid?-but the Pope extolled Geronimo's sillogism. They were only able to stress the hate and the shrewdness behind Geronimo's words. At this stage, SY reworked the quotation from Sanhedrin 97, which blames those calculating the time (of the Messiah). Under the Pope's request, Mattityahu ha-Yișhari visited upon the wrong calculations the absence of hope among the ordinary people. Who calculates the time eventually sins, because he pretends to know the future better than the prophets do. Šĕlomoh ibn Verga explained the Pope's wrath, since Daniel would have been among those blamed. The Papal wrath worsened, when don Todros sarcastically observed 'If the Talmudists are stupid, they cannot offer any proof about the arrival of the Messiah'. Once again, Don Vidal's wisdom asked the Pontiff for mercy. He also dwelt on the difference being in the Hebrew Language between a seer (hozeh), who is alike to a prophet and a simple calculator (mehasheb). The Pope recognized Don Vidal's wisdom and the session comes at an end.

\section{J: February 10th, Day 4}

This time Geronimo introduced a quotation belonging to the Ekah Rabbatia fifth century Midrash about Lamentations-upon which Paul Christiani and Nahmanides fiercely debated in the first day of Barcelona's disputation (Bianchi 1999: 53 \& 19). Relying upon several biblical quotations (the most important was Isaiah 10:34-11:1), Geronimo concluded that the Messiah was born in the same day the Temple was destroyed. R. Astruc ha-Levi from Alcañiz's aljiama echoed Nahmanides's answer, although dating the disputation at the time of the king Pedro III the Great (1276-1285). He reinstated Nahmanides's mistrust in that haggada by means of various interpretations. Some thought that the Messiah was really born in that day, whereas others put him in the Garden of Eden or as still unborn. Under Pope's pressure, r. Mattityahu ha-Yișhari admitted that according to this 
source, the Messiah was born in the day of the destruction of the temple, but he hung his coming on Israel's merits. The Pope interpreted the answer as favorable to Geronimo, whereas Šělomoh Maimon from Tortosa answered in spite of his coreligionists. He referred the incongruous Jewish interpretation to Aristotle's distinction between a thing being in potency and act. The Talmudic quotations meant that the Messiah was born just in potency, as the Hebrew grammar leaves room to translate the verb nolad in different ways. Here the session closed.

Even in this case the Latin Protocols witness some interesting differences. Geronimo summarized the previous session, arguing against $r$. Ferrer's opinion that the phrase 'Messias nondum venit' belonged to the Talmud. Then, he moved to discuss the sources known to us from J. At his turn, r. Astruc would have checked a 'quite old papyrus sheet' (Pacios López 1957: 39), recognizing that the quotation really belonged to the gloss to Lamentations. R. Astruc linked it to the destruction of the First Temple, whereas Geronimo to the Second Temple, without understanding the contradiction with the historical Jesus. The Latin notaries also recorded an exchange between the Pope and r. Astruc. According to this latter, the Jews waited from the Messiah rather temporal goods than the safety of their souls. R. Mattityahu ha-Yișhari and r. Yosef Albo, subscribed to this interpretation, whereas $r$. Todros labeled that Talmudic quotation as a fable. R. Astruc eventually added that only the words of the Bible and of the Talmud were truthful, whereas the sermones - that is to say the haggada-were not. This quotation was in the Talmud, yet. The Latin protocols reported both Šělomoh Yisah's confutation of $r$. Astruc's words and his explanation about the meanings of the verb nolad. The meaning of nolad was 'to be born'.

\section{SY: Day 5}

The fifth day began with the testimoniae brought forth by Geronimo to proof the birth of the Messiah in the day the temple was destroyed and with $r$. Astros's allusion to the Vikkuah Ramban. Although sharing the wrong date of Barcelona's disputation, SY created once again a new text. He ascribed to Fray Paul (Christiani) the opinion that the Jews had to be called Canaanites, whereas the Christians, who replaced them, had to take up the name 'Jews'. Whence did SY draw this idea of substitution, which was applied, elsewhere to the descendants of Sara and Hagar ${ }^{32}$ As far as we know, during the time1350 hold that Christians could have reclaim the name Saracens from the Muslims as following St Paul's exegesis they were the true descendent of Hagar (Klepper 2015: 308-345). 
consuming thirty-seven session (August 2, 1413) Geronimo de Sancta Fide held that the people trusting in the Messiah (i.e. Jesus) deserve to be called Israel (Pacios López 1957b: 299). Did Šělomoh ibn Verga create it upon some memories of this session? Accordingly, SY also fabricated Nahmanides's answer: his antagonist was asked why the Christians did not inherit the Urim and the Tummim besides of the prophecy? ${ }^{13}$ The Pope remarked that Christians did need such things after the coming of Christ. After this lively exchange, SY kept on speaking the birth of Messiah. This question was a pretext for putting once again Don Vidal at the limelight. His answer hinted at Šělomoh Yisa distinction between act and potency, but he abridged Nahmanides's explanation, according to which in each generation there is a man who could be the Messiah if Israel will deserve. Don Vidal added an alleged H. Crescas's opinion, which freed the Messiah from a precise time. The speech fueled Pope's anger who joked about the allegedly Jew's merits and asked for their very opinion. Accordingly, the delegates chose to stick after Nahmanides's opinion. Furthermore, they hinted at the somewhat unclear possibility that the Messiah, just born, could lead the people, whereas Moses needed his brother and the elders to lead a generation of wise men. This last example led the delegates to play down the wisdom of their aljamas where a man alone needed ten leaders. The Pope having agreed, SY introduces the curious speech of a resident from Rome (!), who debated about the verb nolad. How did Šělomoh ibn Verga create this character? Not only has 'the resident of Rome' showed such proficiency into Hebrew, but also into the Talmud. He even quoted the tractate Nedarim 39,6 where the name of the Messiah was one of the seven things created before the creation of the world. Playing with the word creation, this fictitious character hinted at the possible birth of the Messiah in the day of the destruction of the temple. As Riera i Sans (1974: 49, n. 46) remarked, a similar argument surfaced in the thirty-ninth session, but on Geronimo's mouth (Pacios López 1957b: 309). His last words reinstate the idea of the exile as purification for the people's sins. It is quite possible that this character was born, since S Šělomoh ibn Verga located the disputation at Rome.

J: February 11, Day 5, Latin Protocols

The debate resumed on Sabbath, under express order of the Pope. Geronimo still dwelt on the haggada concerning the birth of the Messiah, but the Jewish delegates firmly stood on the previous position. At his turn, the Pope asked how the Messiah, born in the Garden of Eden, could live for two 
thousand years. The Jewish delegates rightly noticed the occurrence of such a question in the disputation of Barcelona (Bianchi 1999: 56-57 \& 39, 65-66 \& 69-70), although they erroneously put it on the mouth of King Pedro. Besides it, they stressed that Methuselah, Noah and Elijah lived in the Garden of Eden. In the heat of the polemics, r. Astruc remarked that the Jews trust in their Messiah, just as the Christians do as to the miracles and prodigies of Jesus. When the debate was reaching a sort of stalemate about the previous Haggada, Geronimo quoted another text from Šělomoh ben Nahman, which started with the words: 'In the day the temple was destroyed...' Unfortunately, J's account stopped here.

According to the Latin Protocols, Mattityahu ha-Yișhari recapitulated what was previously said and he saw in the messiah both the surgeon and the ill. When Geronimo objected that the surgeon must heal the ill as soon as possible, Mattityahu did not answer. Besides, the Latin text remarks that r. Astruc 'respondit non ad propositum'. ${ }^{14}$

SY: Day 6

The account began with the standard chronological annotation 'On the morning when we come back', but there were the Jewish delegates to question Geronimo. The debate about the Hebrew verb nolad went on, as the Jewish delegates pointed out the discrepancy between its meaning in the Talmud ('he was born') and the Scripture (Isaiah 11:1: 'A son will be born to the son of Jesse'). Geronimo countered that this use did not bear 'a chronological proof'. The answer sounded so unconvincing to the Jewish delegates that in their opinion the entire disputation fell down. The following lines described Geronimo, while attempting to recover from his faulty statement. According to Šělomoh ibn Verga, the Jewish delegates saw the victory at hand. They tried to bribe some courtiers for persuading both Geronimo and the Pope to end the disputation. Nevertheless, the Pope answered that the onus of the proof was on Geronimo. It is unclear whether the chronological statement-'in the morning after the reading of the Zakhor'-belongs to the same day or it opens a new session. Riera i Sans (1974: 50 and n. 48) highlights that this reading fell on Saturday February 11,1413 , so that this session would be parallel to the fifth session in J. Šělo-

14 In Baer's opinion (1962: 180) at the end of this session, some 'weak and irresponsible Jews' were obliged to swear on the Law's scroll that the Messiah was already born, as Geronimo held. Oddly enough, the papal notaries registered it only during the fortyseven session of the Latin Protocols (December 22, 1413), when Geronimo summarized the proofs he previously alleged. We can only wonder why the papal notaries did not remember such an event ad diem and whether the swearing was spontaneous or not. No memory survives in the Hebrew sources. 
moh ibn Verga would have used a remark placed on the fringe of Bonastruc' letter. The exchange between the Pope and the delegates closely follow J. The Pope wondered about the presence of the Messiah's in the Garden of Eden, whereas the Jewish delegates stick after Nahmanides' words. In SY narrative, the Pope's skepticism about their answer prompted r. Astruc's tough statement about the Jewish right to believe in their own Messiah. Once again, the Papal wrath burst off and the Jewish delegates blamed r. Astruc and asked for mercy.

SY: Day 7

The Papal wrath vanished at the beginning of the new session, which the Latin Protocols dated on February 13. Geronimo quoted both Šělomoh ben Nahman's remarks with whom J ended and an explanation from Targum Jonathan to the Prophets. This text held that the Messiah would have come just before the disaster and the destruction. After having remarked that $r$. Šĕlomoh ben Nahman did not quote the Targum, the Jewish delegates pointed out the 'ontological' differences between the quotations. Šělomoh ben Nahman said that the Messiah would have come suddenly just as a woman gives birth to a son, whereas the Targum hints at the sudden appearance of the Messiah. According to Šělomoh ibn Verga, this latter remark let the delegates to elaborate the Jewish thoughts about the Messiah. He will gather the Jews wherever they live and he will build the temple with all the people of the Earth. Jesus did not build any temple, yet.

\section{SY: February 15th, Day 8}

After a hiatus of two days, a new session resumed. Surprisingly Salomon Ibn Verga informed the readers that it was February 15. The Pope accused the Jewish delegates for having misled him about the very meaning of nolad. In his opinion, it was not important the grammatical meaning of it, but just the fact that Jesus was born long before the destruction of the temple. Jesus was born in the year 3671 after the Creation, whereas the temple was destroyed in the year 3828, one hundred years after him. In his calculation, Šělomoh ibn Verga mistook of eleven years, as the Jewish chronology put Jesus' birth in 3670 . The gap between the two events is of 157 years. Did SY rework in this case the material, which J ascribed to the second day of the disputation? May be the case, Šělomoh ibn Verga entitled Vidal Benveniste to explain how in the Jewish interpretation of the Scriptures, there is a difference between the literal meaning — the so-called peshat—and a possible secret meaning. After these hermeneutic remarks, Don Vidal emphasized that Geronimo's quotations dealt with Jerusalem's final restoration. 
At this juncture Geronimo quoted Genesis 49:10: 'The scepter will not depart from Judah or a ruler from between his feet until Šiloh shall come'. This testimonium surfaced in the Jewish Christian debate since the XII century, as the school of St Victor and other Christian scholars as well used it. G. Dahan (1991: 496-497) noticed that Rashi's interpretation agreed on its messianic significance (the Targum translated Šiloh as messiaha) and Geronimo knew it. Nevertheless, since Abraham ibn Ezra onwards the Jewish interpreters refused such an interpretation of Genesis 49:10 as too instrumental to the Christian exegesis in favor of an historical explanation. They often considered Šiloh a true, historical member of the House of David. This exegetical feud stirred the debate between Nahmanides who defended the historical interpretation and Paul Christiani (Bianchi 1999: 51-53 \& 11-18). Building upon the hebraica auctoritas of Abraham Ibn Ezra and the Jewish history as well, r. Astruc stressed that Israel did not lost forever the political power (i.e. the scepter) and that the Messiah would have given back the power to Israel. R. Astruc developed another interesting line of thought, as it rests upon the presence of signs and marks in the Biblical text. One of those - the disjunctive accent yetib — stands upon the word 'ad giving to it the meaning of 'forever'. Geronimo fired back by remaking that the Torah was not given with accents and signs. Against the background of the courtier's life, Don Vidal replied that no authority would be stripped away from the Jewish people until the Messiah will come. In opposition to this interpretation, Geronimo drew upon Moshe ha-Darshan who was quoting Rashi's exegesis. Rashi would have ascribed the first part of Genesis 49:10 to the chamber of hewn stones where the Sanhedrin met and the second to the same Sanhedrin. The dissolution of it meant the end of the political power. The Jewish delegates refuted this argument, since Moshe ha-Darshan was not a Talmudist. Furthermore, they ascribed the saying to the patriarch Jacob. Ibn Verga's account stops here. He tentatively wondered that the Jewish delegates went out with great honor and great sufferings as well.

The only mean to verify Šělomoh ibn Verga's report is to follow the Latin Protocols up to February 20, 1413, when the Pope ordered to change the format of the disputation. The Latin Protocols and $J$ as well confirm that the debate about the different meanings of the Scripture occured during the second session. Šělomoh ibn Verga moved them on February 15 (the only other date he gave was January 1). Moreover, the Latin Protocols demonstrate that Šělomoh ibn Verga also shifted to the same day the topics debated on February 13. The same applies to Genesis 49:10. The discussion runs parallel to the Latin source, as far as the duty of the Sanhedrin is concerned. Both SY and the Latin Protocols refer to the liskat ga'azit-the chamber where the Sanhedrin met-but Š̌lomoh ibn Verga made use of this reference to enlighten his ideas about the loss of political power, the 
exile and the Diaspora. It is also noteworthy the accent yetib placed on the word 'ad. The Latin Protocols show that the discussion took place on two rounds. On February 13, r. Astruc illustrated the twofold meaning of this Hebrew particle (in Latin had) namely 'always/forever' or 'until' (Pacios López 1957b: 46). On February 17, r. Ferrer put forth the same observation (Pacios López 1957b: 50-51). According to the Codex Vaticanus of the Protocols, Garcia Alarcon, another Jewish convert, and the theologian Sancio Porta confirmed Geronimo's interpretation after having inquired into the particle. It is not easy to understand why some hints of this debate survived in SY, whereas other facts leaved just a faint trace in the Latin Protocols. For instance, the Latin Protocols did not witness the clash between Geronimo and r. Astruc on a quotation that the Pugio Fidei ascribed to the so-called Rabi Rahamon. A lively debate surrounds this character and his quotations (Lieberman 1939: 66-68, Baer 1962: 178-180, Ragacs 1997: 305-307) Was he a Jewish convert who helped Ramon Martini in writing the Pugio Fidei? Alternatively, was he a fictitious character behind which the same Ramon Martì hided? No sure solution is at hand for the first problem, whereas the quotations could be freely reworking the original.

R. Astruc pointed out that the Jews did not have such an auctoritas. During the session of February 15, the Latin Protocols hinted at Bonastruc Desmestre's sarcastic speech about a quotation from Berešit Rabba (in libro Genesis magno) which the same Rabi Rahamon ascribed to Moshe haDarshan. He refused to comment it unless that auctoritas was found. In this case, too Šělomoh ibn Verga could have generally wrapped it when he told the protest of Jewish delegation about Moshe ha-Darshan's status. Finally there is no evident trace of Mošeh Abenabez's (Sáenz Badillos-Targarona Borrás 1988: 65-66) interview with the Pope to stop he disputation which the Latin protocols record on February 17 (Pacios López 1957b: 53), unless we come back to the sixth day when the Jewish delegates tried to bribe the Pope and the courtiers to end the disputation. All in all, Šělomoh ibn Verga seemingly had some information on the last days of the oral dispute and on some other session as well. Whence he collected them, it is an open question.

\section{Conclusion}

I would like to answer to the questions raised at the beginning of our paper. In my opinion, the scrutiny of the Hebrew sources has shown that J's account really is the main source of Salomon Ibn Verga's narrative. Many details concerning the number of Jewish delegates, their part in the disputation, the agenda during the first week of it and the behavior of the Pope vindicate J's primacy. His shorter account runs smoothly and without amplifications. The comparison with the Latin Protocols confirms it as far as 
the role of r. Zerahyah ha-Levi and r. Astruc ha-Levi and the silence about Vidal Benveniste are concerned. If so, there is room to revaluate Riera $\mathrm{i}$ Sans's proposal, who held upon linguistic and internal arguments the identity between J's account and Bonastruc Desmestre's letter. Although being the only extant Hebrew source, his author did not issue a sort of press report. The long reference to the Vikkuah Ramban placed in the second day reveals a more planned work, although it is impossible to establish whether Bonastruc Desmestre built it upon other letters of the same kind. As matter of fact, from February 1412 up to November 1413, the best of the Jewish intelligentsia was summoned at Tortosa to hear this catechesis. Such a strained situation generated a score of literature spanning from the distressing recollections of Abraham Rimoch (Talmage 1985: 373) or the poems of Salomon Bonafed's (Baer 1962, Bejerano 1989) to more sophisticate works as Vidal Benveniste's Qoděs Qodašim or Y. Albo's Sefer Iqqarim. Beside of these works, other reports could have reached the various aljamas. May be the case, a century later, Š̌lomoh ibn Verga took up the letter, now ascribed to a mysterious Abunastruc and created the fictitious but entertaining story, whose peculiarities has been illustrated in the previous pages. Yet, Vidal Benveniste's portrait deserves a last word: Šělomoh ibn Verga made of him the perfect image of the learned courtier, knowledgeable with the Latin, with the philosophy and the court etiquette. It is difficult to ascertain whether Š̌̌lomoh ibn Verga made use of other sources. The longer list of the Jewish delegates could suggest some addition to Bonastruc's letter. More complex is the use of a Latin source alike to the Latin Protocols held by J. Cohen $(2011,2017)$. This could be true for the last part of his report, where we pinpointed a series of similarities. Where could have Šělomoh ibn Verga or his source read or got them? One of three Latin codices was kept in Gerona, where Andres Bertran was bishop until 1431, but how could they have looked at the codex? An easier solution could be the following one: at the end of sixty-two session, the Pope ordered to provide r. Zerahyah Ha-Levi, r. Mattityahu and r. Astruc with a copy of the first fortyeight sessions (Pacios López 1957a: 37-38; Pacios López 1957b: 556) in order to study them and to move the debate further. Did their texts or notes somewhat reach Šělomoh ibn Verga? Not less singular is the conclusion of the story according to the Šebet Yěhudah. Is it likely that his author keep not any memory of the aljiamas ravaged or deserted after Vicente Ferrer's wandering and enflamed predication (Rusconi 1979: 219-233) or of the conversions which the Latin Protocols and the Spanish sources as well recorded with utter satisfaction ${ }^{15}$ As far the purportedly successful comeback twelfth session, the papal notaries stated that some Jews 'in fonte baptismatis a lepra iudai- 
of the delegates home despite of difficulties and sufferings, did it became another proof of Jewish resilience and an example for those waiting to learn the methods of polemics with the Christians and the enemies of Israel?

\section{Bibliography}

Assis YT (1997) The Golden Age of Aragonese Jewry: Community and Society in the Crown of Aragon, 1213-1327. London and Portland, OR: The Littman Library of Jewish Civilization.

Baer F (1923) Untersuchungen über Quellen und Komposition des Shebet Yehuda. Berlin: C. A. Schwetschke \& Sohn.

Baer YF (1966) A History of the Jews in Christian Spain volume 2. From the Fourteenth Century to the Expulsion. Philadelphia Penn-Jerusalem: The Jewish Publication Society.

Bejerano Escanilla AM (1989) Shelomoh Bonafed. Poeta i Polemista hebreo (s. XIV-XV), tomo I i II, PhD Thesis, Universitat de Barcelona: Barcelona. http://diposit.ub.edu/dspace/handle/2445/41684.

Ben-Shalom R (1991) The Disputation of Tortosa, Vicente Ferrer, and the Problem of the Conversos According to the Testimony of Isaac Nathan (heb). Zion 56(*): 21-54.

Ben-Shalom R (2003) Between Official and Private Dispute. The Case of Christian Spain and Provence in the Late Middle Age. Association Jewish Studies 27(1): 23-71.

Bianchi F (1999) Moshè ben Nachman. La 'Disputa di Barcellona'. Introduzione, traduzione dal testo ebraico e note di Francesco Bianchi. Roma: Edizioni Lamed.

Cantera y Burgos F (1927) Schèbet Yehuda (la Vara de Judà) de Salomon ben Verga-Traduction española con un estudio preliminar. Revista del Centro de Estudios Historicos de Granada y su Reino 13(5): 83-136.

Cantera y Burgos F (1924) Schèbet Yehuda (la Vara de Judà) de Salomon ben Verga-Traduction española con un estudio preliminar. Revista del Centro de Estudios Historicos de Granada y su Reino 14(3-4): 137-296.

Caputo N (2007) Nahmanides in Medieval Catalonia. History, Community, and Messianism. Notre Dame IN: University of Notre Dame Press.

Cohen J (2011) Tortosa in Retrospect: The Account of the Disputation in Solomon Ibn Verga's Ševeț Yehudah (Hebrew). Zion 76(*): 417-452.

ca fuerent mundate' (Pacios López 1957b: 80). It is difficult to ascertain the number of these conversions. In Tortosa, around 3000 Jews asked for the baptism. Overall, the conversions from Catalan and Aragonese aljaimas could have been according a conservative estimate around 20,000 (Foa 2001: 98). 
Cohen J (2016) A Historian in Exile Solomon ibn Verga, 'Shevet Yehudah', and the Jewish-Christian Encounter. Philadelphia PA: University of Pennsylvania.

Dahan G (1990) Les intellectuels chrétiens et les Juifs au Moyen Age. Paris: Cerf.

Del Valle Rodriguez (1998) San Juliàn de Toledo. In Del Valle Rodriguez C and al., La controversia judeocristiana en España [desde los orígenes hasta el siglo 13]. Homenaje a Domingo Muñoz León, Consejo Superior de Investigaciones Científicas, CSIC, Instituto de Lenguas y Culturas del Mediterráneo y Oriente Próximo-ILC: Madrid, pp. 118-130.

Foa A (2001) Ebrei in Europa. Dalla Peste Nera all'Emancipazione, XIV-XIX secolo. Editori La Terza: Roma-Bari.

Girgensohn D (1989) Ein Schisma ist nicht zu beenden ohne die Zustimmung der konkurrierenden Päpste. Die juristische Argumentation Benedikts XIII. (Pedro de Luna). Archivum Historiae Pontificiae 27(*): 197-247.

Girgensohn D (1994) Benedikt XIII. In Lexikon für Theologie und Kirche. Band 2: Barclay bis Damodos. 3. völlig neu bearbeitete Auflage. Herder: Freiburg (Breisgau), pp. 208.

Halberstamm J (1868) Vihhuah Tortosa: Jeshurun de Kobak VI: 45-55, Bamberg (Hebrew).

Klepper DC (2015) Historicing Allegory: The Jew as Hagar in Medieval Christian Text and Allegory. Church History 84(*): 308-344.

Krauss S, Hornbury W (1995) The Jewish-Christian (Texten und Studien zum Antiken Judentum 56). Mohr: Tübingen.

Lieberman S (1939) Shkiin. A Few Words on Some Jewish Legends, Customs, and Literary Sources Found in Caraite and Christian Works. Jerusalem: Bamberger and Wahrmann.

Loeb I (1892) Le folklore juif dans la chronique de Schébet Jehuda d'Ibn Verga. Revue des Etudes Juives 24(*):1-29.

Maccoby H (1993) Judaism on Trial. Jewish-Christian Disputations in the Middle Ages. Portland, OR: The Littman Library of Jewish Civilization.

Niclos JV (2002) La pedra de Toc (Sefer eben bohan) de Shem Tob ben Saprut. Llibre Primer: 'Sobre els fondaments de la $f e$ '. Universitad de Barcelona: Barcelona.

Pacios López A (1957a) La disputa de Tortosa, volum I: Estudio historico-critico doctrinal. Madrid-Barcelona: Instituto Arias Montano.

Pacios López A (1957b) La disputa de Tortosa volum II: Actas. MadridBarcelona: Instituto Arias Montano.

Posnanski A (1922) Le colloque de Tortose et de San Mateo (7 fevrier 141313 Novembre 1414). Revue des Etudes Juives 74(*): 17-39.

Posnanski A (1922) Le colloque de Tortose et de San Mateo (7 fevrier 141313 Novembre 1414). Revue des Etudes Juives 74(*): 160-168. 
Posnanski A (1923) Le colloque de Tortose et de San Mateo (7 fevrier 141313 Novembre 1414). Revue des Etudes Juives 75(*): 74-88.

Posnanski A (1923) Le colloque de Tortose et de San Mateo (7 fevrier 141313 Novembre 1414) in Revue des Etudes Juives 75(*): 187-204.

Poznanki A (1923) Le colloque de Tortose et de San Mateo (7 fevrier 141313 Novembre 1414). Revue des Etudes Juives 76(*): 37-46.

Ragacs U (1998) Raimundo Martí, O.P. biografía. In Del Valle Rodriguez C and al., La controversia judeocristiana en España [desde los orígenes hasta el siglo 13]. Homenaje a Domingo Muñoz León. Consejo Superior de Investigaciones Científicas, CSIC, Instituto de Lenguas y Culturas del Mediterráneo y Oriente Próximo-ILC: Madrid, pp. 301-308.

Rauschenbach S (2002) Josef Albo: Jüdische Philosophie und christliche Kontroverstheologie in der Frühen Neuzeit [Studies in European Judaism, volume 3]. Leiden: Brill.

Riera i Sans J (1974) La crònica en hebreu de la disputa de Tortosa. Barcelona: Fundació Salvador Vives Casajuana.

Roth N (1986) Seis edades durerà el mundo. Temas de la polemica judeoespañola. La Ciudad de Dios 199(1): 45-65.

Rusconi R (1979) L'attesa della fine: crisi della società, profezia ed Apocalisse in Italia al tempo del grande Scisma d'Occidente (1378-1417). Roma: Istituto Storico Italiano per il Medioevo.

Sáenz Badillos A, Targarona Borrás J (1988) Diccionario de Autores Judios (Sefarad, Siglos X-XV). Cordoba: Ediciones El Almendro.

Schreckenberg H (1994) The christlichen Adversus-Judaeos. Texte und ihr Literarischen und historisches Umfeld. Peter Lang: Frankfurt am Main.

Schwarz AZ (1931) Die Hebraischen Handschriften in Österreich. Teil 1: Bibel bis Kabbala. Leipzig: Hiersemann.

Šelomoh Ibn Verga (1947) Sefer Ševet Yehudah lerabbi Shelomoh zy Verga, eds. A. Shohat \& Y. Baer. Mossad Bialik: Jerusalem.

Selomoh Ibn Verga (1991) La Vara de Yehudah (Sefer Shebet Yehudah), Cano MJ (introduction, traduction y notas). Riopedras Ediciones: Barcelona.

Simonsohn S (1989) The Apostolic See and the Jews: Documents, 1394-1464 (Studies and Texts 95). Pontifical Institute of Medieval Studies: Toronto.

Sirat C (2000) La filosofia ebraica medievale secondo $i$ testi editi e inediti. Paideia Editrice: Brescia.

Talmage FE (1985) Trauma at Tortosa: The Testimony of Abraham Rimoch. Medieval Studies 47(*): 379-415.

Vaquero Piñeiro M (2000) Benedetto XIII: Antipapa. In Enciclopedia dei Papi. Available at http://www.treccani.it/enciclopedia/antipapa-benedettoxiii_-(Enciclopedia-dei-Papi)/.

Vendrell F (1953) La actividad proselitista de san Vicente Ferrer durante el reinado de Fernando I de Aragón. Sefarad 13(*): 87-104. 
Williams AL (1935) Adversus Judaeos. A Bird's-Eye View of Christian Apologiar until the Renassaince. Cambridge: Cambridge University Press.

\section{Postscriptum}

While waiting for proof-reading of the text, some valuable papers dealing with different aspects of the Tortosa's Disputation came to my attention. C. del Valle Rodriguez (2010: 203-215) pinpointed that a manuscript written in the 15 th century witnesses a Spanish version of the Disputation. The text so far published roughly covers the first day of the Disputation kept in the Latin Protocols (on February 7, 1413), although it hints at the materials that Geronimo de Santa Fè provided to the rabbis in view of the debate. C. del Valle Rodriguez 2010: 203) holds that 'no one is the translation of the other'. As far as the original language of the Disputation, C. del Valle Rodriguez (2017: 211-216) has recently assumed that the debates between Geronimo and the rabbis were hold in Hebrew and only later translated into Latin. A document kept in Vatican Secret Archive would demonstrate that the Papal Court payed the Spanish Cleric Pero de Buesa in order to translate the Hebrew text into Latin. Nevertheless, this hyphotesis does not seem quite convincing: at this stage of its development, Hebrew was a written language and I wonder how the Jewish populace forced to attend the Disputation could have understood it. Following J. Perarnau i Espelt (1984: 254-255) who first edited the aforementioned Latin document, Pero de Buesa would have translated only the Jewish Cedulae, that is to say the Jewish text which the rabbis presented for the sake of discussion. As a medium for the debate, it is better to think of a Romance language (Catalan, Castillan). On the Wirkungsgeschichte of the proofs about the Messiah hold by Geronimo de Santa Fé, see M. Silvera (2017).

\section{Bibliography}

Del Valle Rodríguez C (2010) La disputa de Tortosa: la antigua versión original hispana de las Actas. Iberia Judaica 2(*): 203-215.

Del Valle Rodeiguez C (2017) Atalaya del Judaismo Hispano VI. 5. Una disputa judeocristiana en hebreo: la disputa de Tortosa (1412-1414). Iberia Judaica 10(*): 211-216.

Perarnau i Espelt J (1984) El Traductor de la Disputa de Tortosa de l'Hebreu al Llatì. Arxiu de textos catalans antics 3(*): 254-255.

Silvera M (2017) Quando Dio deciderà di redimere Israele: vera e falsa Redenzione nel pensiero di Isaac Orobio de Castro. Sefarad 77(2): 405422.

Acknowledgement. I would like wholeheartedly to thank R. Magdalena Nom de Dieu and D. V. Proverbio for their invaluable help during various stage of this paper. 